\title{
Disease, illness, sickness, health, healing and wholeness: exploring some elusive concepts
}

Kenneth M Boyd Edinburgh University Medical School and The Institute of Medical Ethics

\begin{abstract}
Concepts such as disease and health can be difficult to define precisely. Part of the reason for this is that they embody value judgments and are rooted in metaphor. The precise meaning of terms like health, healing and wholeness is likely to remain elusive, because the disconcerting openness of the outlook gained from experience alone resists the reduction of first-person judgments (including those of religion) to third-person explanations (including those of science).

(F Med Ethics: Medical Humanities 2000;26:9-17)
\end{abstract}

Keywords: Health; disease; healing; wholeness; illness; sickness

\section{Introduction}

In this paper, I want to explore possible meanings of a cluster of words-disease, illness, sickness, health, healing and wholeness. Many people have tried to elucidate what these words mean, but agreed definitions are often elusive. In what follows I shall begin with some definitions of disease, illness and sickness. I shall then try to say why definitions of disease and health are so elusive; and I shall end with some observations on science and religion, in the light of which the difficulty of defining health, healing and wholeness may make some kind of sense.

\section{Dictionary definitions}

Dis-ease (from old French and ultimately Latin) is literally the absence of ease or elbow room. The basic idea is of an impediment to free movement. But nowadays the word is more commonly used without a hyphen to refer to a "disorder of structure or function in an animal or plant of such a degree as to produce or threaten to produce detectable illness or disorder"-or again, more narrowly, to "a definable variety of such a disorder, usually with specific signs or symptoms or affecting a specific location". That at least is how the New Shorter Oxford Dictionary ${ }^{1}$ defines it, adding as synonyms: “(an) illness”, “(a) sickness”.
Let me stay with the dictionary to see what it says about those synonyms.

Illness has three definitions. Two of them are of the way the word was used up to the 18th century-to mean either "wickedness, depravity, immorality", or "unpleasantness, disagreeableness, hurtfulness". These older meanings reflect the fact that the word "ill" is a contracted form of "evil". The third meaning, dating from the 17 th century, is the modern one: "Ill health; the state of being ill". The dictionary defines "ill" in this third sense as "a disease, a sickness". Looking up "sickness" we find "The condition of being sick or ill; illness, ill health"; and under "sick" (a Germanic word whose ultimate origin is unknown, but may be onomatopoeic) we find "affected by illness, unwell, ailing ... not in a healthy state", and, of course, "having an inclination to vomit".

There is a rather unhelpful circularity about these dictionary definitions. But dictionaries of the English language usually only aim to tell us the origins of words and how they have been used historically. They do not aim at the much more contestable goal of conceptual clarity. For that we have to look elsewhere. In this case, let us look at how disease, illness and sickness have been elucidated first by a medical practitioner, who ought to know something about the subject; and then, after noting some popular and literary definitions, by a philosopher, who ought to know something about conceptual clarity.

\section{A medical definition}

Professor Marshall Marinker, a general practitioner, suggested over twenty years ago a helpful way of distinguishing between disease, illness and sickness. He characterises these "three modes of unhealth'"'as follows.

"Disease ... is a pathological process, most often physical as in throat infection, or cancer of the bronchus, sometimes undetermined in origin, as in schizophrenia. The quality which identifies disease is some deviation from a biological norm. 
There is an objectivity about disease which doctors are able to see, touch, measure, smell. Diseases are valued as the central facts in the medical view...

"Illness ... is a feeling, an experience of unhealth which is entirely personal, interior to the person of the patient. Often it accompanies disease, but the disease may be undeclared, as in the early stages of cancer or tuberculosis or diabetes. Sometimes illness exists where no disease can be found. Traditional medical education has made the deafening silence of illness-inthe-absence-of-disease unbearable to the clinician. The patient can offer the doctor nothing to satisfy his senses..

"Sickness ... is the external and public mode of unhealth. Sickness is a social role, a status, a negotiated position in the world, a bargain struck between the person henceforward called 'sick', and a society which is prepared to recognise and sustain him. The security of this role depends on a number of factors, not least the possession of that much treasured gift, the disease. Sickness based on illness alone is a most uncertain status. But even the possession of disease does not guarantee equity in sickness. Those with a chronic disease are much less secure than those with an acute one; those with a psychiatric disease than those with a surgical one ... . Best is an acute physical disease in a young man quickly determined by recovery or death - either will do, both are equally regarded."

Disease then, is the pathological process, deviation from a biological norm. Illness is the patient's experience of ill health, sometimes when no disease can be found. Sickness is the role negotiated with society. Marinker goes on to observe that a sizeable minority of patients who regularly consult general practitioners, particularly for repeat prescriptions, suffer from none of these modes of ill health. They appear, rather, to be seeking "to establish a healing relationship with another who articulates society's willingness and capability to help". So a "patient", in the sense of someone actively consulting a doctor rather than just being on the books, does not necessarily mean someone who has a disease, feels ill, or is recognised to be sick; and of course there are other more mundane reasons, short of wanting to establish a healing relationship, why a patient may consult a doctor - to be vaccinated before travelling abroad for example. Most patients most of the time however, probably can be classified as having a disease, or feeling ill, or being recognised as sick.

\section{Popular and literary definitions}

For some patients, the last of these may be the most important. Recently I was handing out to a class of medical students the General Medical Council's booklets on The Duties of a Doctor. The university janitor who was helping me unpack them remarked: "As far as I'm concerned the main duty of a doctor is to give me a sick note, otherwise I won't get sick pay". A week later, on a train, I met a recently unemployed man who recounted to me at some length how he had cajoled his general practitioner into signing him off for a few months longer, so that he could keep on getting sick pay until he got to pensionable age. And according to Hystories, by the American critic Elaine Showalter, ${ }^{3}$ new ways of getting recognised as sick are being found all the time. Modern culture is continually spawning hysterical epidemics - in the pre-millennial years, ME, Gulf war syndrome, recovered memory, multiple personality syndrome, satanic abuse and alien abduction. These, a sympathetic reviewer of the book explained, were examples of:

"the conversion of emotional pain and conflict into the camouflaged but culturally acceptable language of body illness... . Typically, individuals who are unhappy or unfulfilled in their lives develop diffuse and evolving nervous complaints and eventually seek help. A physician, or some other scientific authority figure, concocts 'a unified field theory providing a clear and coherent explanation for the confusing symptoms', as well as a new and a memorable name for the sydrome. This explanation draws on contemporary disease theory, usually viral and immunological ideas. An individual case or two, often involving a wellknown public personality, provides a popular paradigm for the new synthesis of symptoms. A best selling novel ..., soon to become a major motion picture, first advertises the syndrome to a large audience. Magazine stories and television documentaries further publicise the symptoms. High-profile books for persons seeking information appear, as do patients' autobiographies. Most recently, daily talk-shows, those agencies of mass pop psychotherapy, unite sufferers and therapists in order to dramatise their life stories and to explain the meaning of their disorder for millions; in the process, participants cite enormous projected numbers of the afflicted and encourage others to come forward... . These are acutely communicable diseases... ."

So the reviewer, expounding Showalter, claims. People with ME and Gulf war veterans, by contrast, understandably might contest this view of what they are suffering from; and more 
scientific findings about the veterans' health ${ }^{5}$ have appeared since Hystories was published in 1997. Showalter's argument nevertheless helps to illustrate Marinker's useful distinction between disease, illness and sickness. Whether or not someone is ill, is something the person concerned ultimately must decide for him- or her-self. But whether that person has a disease or is sick is something doctors and others may dispute.

\section{Munchausen's syndrome}

Some diseases, clearly, are less respectable than others. A classic example is Munchausen's syndrome, the diagnostic label applied to people who repeatedly present themselves to hospitals with convincing symptoms, often demanding and sometimes undergoing surgery which reveals no organic disorder. People with Munchausen's syndrome may seem reminiscent of Marinker's repeat prescription patients who seek "a healing relationship with another who articulates society's willingness and capability to help". But their condition is more likely to be dismissed as "a bizarre form of malingering" or "the systematic practice of deliberate and calculated simulation of disease so as to obtain attention, status and free accommodation and board". ${ }^{7}$ Most of them, it may be explained, "are suffering from psychopathic personality or personality defect", a condition defined as being "characterised by impulsive, egocentric and antisocial behaviour", with "a difficulty in forming normal relationships, and a manner which is either aggressive or charming or which alternates between the two". ${ }^{8}$ That, it might be observed, makes them sound suspiciously like people who have not had the opportunity or luck to end up as successful politicians or captains of industry.

People labelled with Munchausen's syndrome then, may have succeeded in getting recognised as being sick, but not in the sense they intended. In Marinker's terms, their sickness has pretty low status. It is doubtfully a disease, and as illness its meaning veers more towards the pre- than post-18th century usage- - "wickedness, depravity, immorality". Such words, or the colloquial "sick, sick, sick", are even more likely, of course, to be applied to the perpetrators of Munchausen syndrome by proxy - people who abuse a child or frail elderly relative by making them ill or pretending that they are ill.

\section{Philosophers' questions}

Are such people mad, or bad? How do you answer such a question? To try to find a more helpful way of framing it, let me move on to the purveyors of conceptual clarity, the philosophers. To doctors,
Marinker suggests, disease is the most tangible mode of unhealth. When they talk about disease, they know what they mean. Philosophers are less sure. R M Hare, for example, asks:

"Why do attacks of viruses count as diseases, but not the attacks of larger animals or of motor vehicles? Is it just a question of size? Or of invisibility? I believe that doctors call the attacks of intestinal and other worms diseases, though there are also more precise words like 'infestation'. If I have a tape or a guinea worm (which are quite large), do I have a disease? Does it make a difference if the worm can be seen but its eggs cannot? Or does it make a difference that the worm, although it can eventually be seen, is in some sense, while active, inside the patient, whereas dogs and lorries, and also lice and fleas, whose attacks are likewise not called diseases, are always outside the body? Does a disease have to be something in me? And in what sense of 'in'? Some skin diseases such as scabies are so called, although the organisms which cause them are on the surface of the skin, and do not penetrate the body. They penetrate the skin indeed; but then so does the ichneumon maggot, and the body too. Is the difference between these maggots and the scabies mite merely one of size? Or of visibility?"9

Well perhaps, Hare suggests, we just use the word "disease" for "conditions whose cause was not visible before the invention of microscopes". But a more basic point, he adds, is that "in order to identify a condition as a disease we ... have to commit ourselves to there being a cause, ascertainable in principle, of the same sort as the causes of diseases whose aetiology we do understand". What I take Hare to mean by this, is that when doctors apply a diagnostic label like Munchausen's syndrome, for example, they are committing themselves to the hope that someday they will be able to understand-in medical terms ("mentally ill" or "mad"), rather than moral ones ("bad") - what makes these people act in the way they do.

But what does "understand in medical terms" mean in this context? Does it mean that doctors hope to find some causative agent in the patient, or in the patient's environment? Or does it just mean that they are robustly rejecting Kant's demand "that all the insane be turned over to the philosophers and that the medical men stop mixing into the business of the human mind"10 - in the vague hope that a therapeutic approach will eventually prove to be more effective than a moral or legal one? And what are we to make of the fact that doctors have chosen to label Munchausen's syndrome by the name of a fictional liar, rather 
than by the name of the distinguished psychiatrist who first identified it, or by some medical term which suggests the direction in which they are looking for an explanation? Applying the disease label to this, and maybe some other conditions, sounds not very different from what St Anselm called fides quaerens intellectum, "faith seeking understanding"-although in this case the doctors sound rather less optimistic about finding a cause than St Anselm was about proving the existence of God.

At this point, of course, doctors might protest that theorising around an example like Munchausen's syndrome is more typical of philosophy than of more everyday medical practice, in which medical faith, seeking understanding, has repeatedly found it. I think that response is fair. But to be fair to philosophers too, let me add that Hare is not arguing that "disease" is a kind of linguistic weapon wielded by doctors in order to get patients to submit to them. His point rather is that the word "disease" has an evaluative character. Using it can be justified, if patients and doctors evaluate it in the same way-if patients agree with their doctors that the disease is bad for them. But it becomes problematic when this agreement is absent. This suggests one reason then, why definitions of disease can be so elusive. To call something a disease is a value judgment, relatively unproblematic in cases when it is widely shared, but more contentious when people disagree about it.

\section{Health}

When philosophers try to define health some of them reach a similar conclusion. R S Downie for example, agrees that the World Health Organisation definition of health - as "a state of complete physical, mental and social wellbeing, and not merely the absence of disease or infirmity"-is overambitious. Nevertheless, he argues, it is probably aiming in the right direction. ${ }^{11}$ To try to define health as simply the absence of disease or infirmity leads you into difficulties: ill health can't be defined simply in terms of disease, for example, because people can have a disease (especially one with minor symptoms) without feeling ill, and they can have unwanted symptoms (nausea, faintness, headaches and so on) when no disease or disorder seems to be present. Nor is the fact that a condition is unwanted enough to describe it as ill health: it may be the normal infirmity of old age for example; and again a condition's abnormality is not enough either - a disability or deformity may be abnormal, but the person who has it may not be unhealthy; and much the same may apply to someone who has had an injury. To say whether or not physical ill health is present therefore, a complex combination of "abnormal, unwanted or incapacitating states of a biological system may have to be taken into account". And things are even more complicated when assessing mental ill health. Abnormal states of mind may reflect minority, immoral or illegal desires which are not sick desires. On the other hand, a psychopath, for example, may neither regard his state as unwanted, nor experience it as incapacitating.

The problem, however, is not just that ill health can be difficult to pin down. It is also that we normally think of health as having a positive as well as a negative dimension. But here again things are complicated. A positive feeling of wellbeing, for example, may not be enough. As Downie says: "it would be difficult to make a case for viewing an acute schizophrenic state with mood elevation and a blissful lack of insight as one of positive health". Nor is fitness sufficient: the kind of fitness sought in athletic training, indeed, is sometimes detrimental to physical health; and the desire to maximise physical fitness as an end in itself may become an unhealthy obsession. Often, what is required is only a "minimalist" notion of fitness, age-related and geared to everyday activities.

"True" wellbeing, Downie goes on to suggest, requires (a) an "essential reference to some conception of the 'good life' for a human being" and (b) "some conception of having a measure of control over one's life, including its social and political dimensions". Those factors, as well as the complex negative side, have to be taken into account when we ask what "health" means. But even when we have taken all these factors into account, we cannot quantify how healthy an individual is with any precision. That is not just because the sum is complex. It is also, Downie concludes, agreeing with Hare, because the components include value judgments.

\section{Value judgments and metaphors}

One reason then, why definitions of disease and health are sometimes so frustratingly elusive is the part played by value judgments in determining what we mean by disease and health as well as what we mean by illness and sickness. In many cases this is not obvious, because most people, in our society at least, make the same or similar value judgments about what these words mean and what are examples of what they mean. There is, as it were, a common core of ideas about what disease is or what health is. But beyond that common core, judgments on whether a condition is a disease, or on what or who is healthy, begin to diverge, and our conceptions of disease and health begin to get fuzzy. 
Another way of understanding this, I think, has to do with the important part played by metaphor in the development of thought and language. When we want to talk about some new experience or discovery for which our existing terminology has no adequate resources, a metaphor-a word or words from some other area of experience, but used in a new way-may help us to say what we mean. Some thinkers, for example Nietzsche, and before him Shelley and Coleridge, have argued that all language develops by metaphorising and by metaphors becoming accepted as "literal". Our language, they say, is littered with "dead metaphors"; and this includes our scientific language. My own favourite example of the role played by creative metaphorising in science is one which I once copied into a notebook from an article about the brain in (I think) the Scientific American:

"Axons sprout new endings when their neighbours become silent and the terminal branches of dendritic arbors are constantly remodeled."

I find those metaphors drawn from arboriculture to neurophysiology, not only profoundly encouraging, given my own aging brain, but also poetically inspired.

\section{Health as a metaphor}

In the case of disease, I have already indicated how metaphorising seems to have been at work, in the development of this more specific term as a particular instance of something causing dis-ease and making for lack of elbow room or freedom of movement. Health as a metaphor may be more complex. The word derives from an old Germanic root meaning wholeness. But the most influential example, in the metaphorising process, of the idea of wholeness, may have been that of the breeding animal at the peak of its performance. If that is right, it may be part of the reason why, as the anthropologist Edmund Leach suggests, "subliminally the general public's idea of good health is all mixed up with ideas about sexual vigour"; and why, despite

"the obvious discrepancy from reality, the model of ideal good health which ordinary members of the public pick up, through the visual images of the Press and the TV screen, and from the verbal suggestions of their doctors, is closely related to the classical ideal of the youthful Greek athlete."12

A further point perhaps worth noting here, is that once metaphors get going, they can be hard to stop. Humans are highly imitative animals. During the last general election for example, I noticed the habit of using the word "Look..." as a punchy introduction to a line of often oversimplified argument, spread first among radio interviewers and then to politicians, including eventually Tony Blair. It was, I felt, a rather irritating habit. But after a symposium I took part in soon after the election, I realised that not only had one of the other speakers used "Look..." in the same way, but so had I. Our imitative or mimetic tendency then, may be one of the reasons why successful metaphors tend to proliferate so successfully.

\section{Spiritual health}

In the case of "health", we can see this happening as the metaphor expands from bodily health, to include spiritual health (the Anglican prayer book's phrase, "there is no health in us"), then political health (Shakespeare's Hamlet refers to the "safety and health of the whole state"), and finally to ordinary usage today when we refer to someone having a healthy or unhealthy attitude and so forth.

Now none of this, perhaps, causes much trouble if we understand that these are metaphors when we use them to orientate our thought and action. In many cases moreover, expanding metaphors usually only modify rather than radically alter thought or action already also oriented by other powerful metaphors. For example, to call an accountant a "company doctor" doesn't excuse his "doctoring the books" when an authority holds an "accountant" "accountable". But problems may arise when a metaphor expands in a sphere where it is not challenged or complemented by other equally powerful metaphors which are also expanding. In that case the metaphor in question may go on expanding its application almost indefinitely.

Something like this, I think, has happened in the case of "health", as a result of the declining vitality of religious metaphors in Western, or at least European, public discourse. Metaphorical ideals such as "healthy behaviour" and "mental health", propounded by doctors and others who are perceived to be "objective" and to have no ideological axe to grind, have expanded to fill the vacuum as it were. The absence of any metaphors more convincing than therapeutic ones, thus may help to explain why applying even such a label as "Munchausen's syndrome" seems to many people the best hope of understanding that morally ambiguous condition. Similar reasons perhaps may also help to explain why the language of ethics, again perceived as "more objective" than that of religion, now plays an increasingly important role in Western public discourse. One difficulty about this perception of ethics however, is that it encourages the expectation that ethics should be able to deliver definitive "answers"-just as the 
public rhetoric of health encourages the expectation that health is something that it ought to be possible, not only to define, but also to achieve.

\section{No health as such}

"A medical man", Sir William Jenner once remarked" $^{13}$ "needs three things. He must be honest, he must be dogmatic and he must be kind". A philosopher, by contrast, needs only the first of these. One of the most relentlessly honest philosophers was Nietzsche. Let me quote something he once wrote about health, to echo rather more forcefully what I have been trying to say so far:

"there is no health as such, and all attempts to define anything in that way have been miserable failures. Even the determination of what health means for your body depends on your goal, your horizon, your energies, your drives, your errors, and above all on the ideals and phantasms of your soul. Thus there are innumerable healths of the body; and ... the more we put aside the dogma of 'the equality of men', the more must the concept of a normal health, along with a normal diet and the normal course of an illness be abandoned by our physicians. Only then would the time have come to reflect on the health and sicknesses of the soul, and to find the peculiar virtue of each man in the health of his soul: in one person's case this health could, of course, look like the opposite of health in another person."14

\section{Normal and normative}

Nietzsche claims that we should abandon the concept of a normal health. Let me use that, and his reference to the soul, as a starting point for what I promised to say about science and religion. In this connection, a helpful contrast was drawn by the medical philosopher and historian Georges Canguilhem between two views of what is normal. On the one hand there is the view of disease or malfunction as a deviation from a fixed norm established by medical theory, to which norm medical practice seeks to return the patient. On the other there is the view of the organism as a living being that has no pre-established harmony with its environment. The latter, Canguilhem argues, is the true view of normality. "Being healthy", he writes:

"means being not only normal in a given situation but also normative in this and other eventual situations. What characterises health is the possibility of transcending the norm, which defines the momentary normal, the possibility of tolerating infractions of the habitual norm and instituting new norms in new situations." 15
Perhaps a more colloquial way of putting what Canguilhem says here is that health is not a matter of getting back from illness, but getting over and perhaps beyond it. Health, to quote Canguilhem again:

"is a feeling of assurance in life to which no limit is fixed. Valere, from which value derives, means to be in good health in Latin. Health is a way of tackling existence as one feels that one is not only possessor or bearer but also, if necessary, creator of value, establisher of vital norms."16

On this view then, to be healthy is not to correspond with some fixed norm, but to make the most of one's life in whatever circumstances one finds oneself, including those which in terms of some fixed norms may seem severely impaired or unhealthy. "To be in good health", Canguilhem writes, "means being able to fall sick and recover".

\section{The scientific picture}

Canguilhem also, like Leach, comments on the "seduction still exerted on our minds today by the image of the athlete" as the image of health, agreeing on its inappropriateness as an ideal for practically all of the population. Why is this view so seductive? Perhaps because we tend to assume that a modern scientific or "objective" picture of the world, in which we ourselves figure as natural phenomena, is the "true" view of the "real" world. In this scientific picture, it is difficult not to see something like the image of the athlete as the ideal of health-for which all that comes before is a preparation, and all that follows a process of disintegration and decay.

But there is a serious problem about taking this objective scientific picture as the "true" view of the "real" world. The physicist Schrödinger put it as follows. ${ }^{17}$ The only way scientists can "master the infinitely intricate problem of nature", is to simplify it by removing part of the problem from the picture. The part that scientists remove is themselves as conscious knowing subjects. Everything else, including the scientists' own bodies as well as those of other people, remains in the scientific picture, open to scientific investigation. This "objective" picture is then taken for granted as "the 'real world' around us"; and because it includes other people who are conscious knowing subjects just as the scientist is, it is difficult for the scientist to resist the conclusion that the "true" picture of the "real world" must be an "objective"picture, which includes the conscious knowing subject as another object. That conclusion, however, fails to fit all the facts. For, as Schrödinger says, this "moderately satisfying [scientific] picture of the world has only been reached 
at the high price of taking ourselves out of the picture, stepping back into the role of a nonconcerned observer".

The point Schrödinger is making can be difficult to grasp, or at least to hold on to, because the view that an "objective" picture is the "true" picture of the "real world" seems like common sense. It is reflected, for example, in what David Chalmers, in The Conscious Mind, ${ }^{18}$ characterises as "Don't-have-a-clue materialism"-the view "held widely, but rarely in print" which says "I don't have a clue about consciousness. It seems utterly mysterious to me. But it must be physical, as materialism must be true". The problem is that all of us, before we begin to think critically about such questions, have come to experience the world and other people as things "out there", either inanimate or animate. So is not that, ultimately, the true picture of us also? To deny it feels unreasonable - as unreasonable as it must once have felt to deny that the sun went round the earth. Yet just as science once destroyed that illusion, so too now, science itself is destroying the modern illusion that the "true" picture of the "real world" is an objective one which science, when it has made all its discoveries, will eventually provide.

\section{Interplay}

This message of course has been underlined by modern physics's realisation that, as Schrödinger puts it, "the object is affected by our observation. You cannot obtain any knowledge about an object while leaving it strictly isolated". Or as Heisenberg observed:

"Science no longer confronts nature as an objective observer, but sees itself as an actor in this interplay between man and nature. The scientific method of analysing, explaining and classifying has become conscious of its limitations, which arise out of the fact that by its intervention science alters and refashions the object of investigation."19

"Science no longer confronts nature as an objective observer, but sees itself as an actor in this interplay between man and nature." The problem about conceiving health in terms of fixed norms such as those of biochemistry, or the ideal of the athlete, is that it assumes that the objective observer's viewpoint is the true one, and discourages those who adopt it from seeing themselves as actors or agents, rather than patients who are acted upon. Daniel Dennett has remarked that "human beings offload as much of their minds as possible into the world". ${ }^{20}$ If we want to gain a more adequate understanding of the meaning of "health", along the lines Canguilhem suggests, we may have to be prepared to offload rather less, and take responsibility for rather more, of our minds.

That at least seems to be what science itself is now telling us; and in that respect science provides part of the explanation of why definitions of health are, and are likely to remain, elusive. If health is "a way of tackling existence" in which "one is not only possessor or bearer but also, if necessary, creator of value, establisher of vital norms", then what constitutes health in one person may well, as Nietzsche said, "look like the opposite of health in another person".

\section{Religious ideas}

The final part of the explanation I want to suggest concerns religion. A naïve, albeit widely-held view, is that religious ideas about the world have been disproved by science. What actually happened historically is more complex. Schrödinger again provides a helpful explanation:

"One of the aims, if not perhaps the main task of religious movements has always been to round off the ever unaccomplished understanding of the unsatisfactory and bewildering situation in which man finds himself in the world; to close the disconcerting 'openness' of the outlook gained from experience alone, in order to raise his confidence in life and strengthen his natural benevolence and sympathy towards his fellow creatures-innate properties, so I believe, but easily overpowered by personal mishaps and the pangs of misery."21

Religion, Schrödinger suggests, has always tried to "round off" or "close the disconcerting 'openness"" of human experience. In the past, it has done this, often very successfully, in terms of scientific or pre-scientific ideas which at the time seemed plausible to everyone. When these ideas were overtaken by new scientific explanations which seemed to fit the facts better, religion, being more conservative than science, was slow to give them up; and this helped to create the impression among many people that it was only a matter of time before science would explain everything. But this idea of science demonstrating "a selfcontained world to which God" (or the religious or transcendent dimension) is "a gratuitous embellishment", Schrödinger points out, begins to seem unrealistic when we grasp what he is saying about the absence of the conscious knowing subject from the scientific picture of the world. If science were able to exclude the religious or transcendent dimension from reality (rather than just from the scientific picture of reality), it would be at the cost of excluding the first-person human dimension also. But the idea that science can do this, Schrödinger adds, springs not "from people 
knowing too much-but from people believing that they know a great deal more than they do".

Insights such as Schrödinger's have not been lost on many more perceptive modern religious thinkers, who see no necessary conflict between religious and scientific ideas. One of the defining attitudes of science, Schrödinger points out, is that in "an honest search for knowledge you quite often have to abide by ignorance for an indefinite period". ${ }^{22}$ But such an acknowledgement of ignorance is also what is required by the JudaeoChristian rejection of idolatry-superstitious mental pictures or preconceived notions which inhibit open-minded attention to reality in all its variety - and this religious rejection of idolatry, it has often been argued, was what opened the way for modern scientific enquiry. The scientific fides quarens intellectum, moreover, has a strong family resemblance to religious faith as described by two key modern religious thinkers-Kierkegaard, when he remarked that "not only the person who expects absolutely nothing does not have faith, but also the person who expects something particular or who bases his expectancy on something particular"23; and Coleridge, when he wrote that faith "may be defined as fidelity to our own being - so far as such being is not and cannot become an object of the senses; and hence ... to being generally, as far as the same is not the object of the senses." 24

Religious statements of this kind illustrate not only the compatibility of science and religion, but also that the idea of a healthy person as a "creator of value, establisher of vital norms" can be endorsed by religion. Coleridge's famous description of the imagination as "a repetition in the finite mind of the eternal act of creation in the infinite I AM", ${ }^{25}$ for example, implies that religious knowledge of what it calls "God" is analogous not to what is seen by an objective observer, but to what is encountered by Heisenberg's "actor in the interplay". That this encounter is with reality, is in no way diminished by its taking place through the creative human imagination.

\section{Wholeness, healing and death}

For religion, the two remaining words I mentioned at the outset - wholeness and healing - are intimately related. Healing is understood by religion not only as the natural process of tissue regeneration sometimes assisted by medical means, but also as whatever process results in the experience of greater wholeness of the human spirit. Healing in the latter sense need not be religious in form (nature, music or friendship as well as religious rites may be agents of healing), nor accompanied by "cures" or "miracles". These or other signs of hope, when attested, may be seen as traces of a transcendent or encompassing wholeness, in which human wholeness is grounded. But wholeness is always imperfectly realised in the fragmentariness of human experience; and while for religion the encompassing wholeness is not reducible to a psychological projection, it is discovered most commonly in the mode of expectancy, both in the midst of life and in the face of death.

\section{Religious expectancy}

Religious expectancy clearly is not something on which science can have much to say, except perhaps to discourage religion when it too rapidly or rhetorically seeks to close the "disconcerting openness" of experience by interpreting its own experience and expectancy in terms of "something particular"-clinical trials to prove the power of prayer or the validity of near-death experiences, for example. But whether or not religious experience and expectancy represent more than psychological reality, remains part of the disconcerting openness of human experience, which can be closed or rounded off no more conclusively by scientific experiment than by religious dogma. Such questions admit only answers given, not by detached scientific or religious observers, but by or between conscious knowing subjects, the actors in the interplay.

This disconcerting openness perhaps is what, finally, makes the meaning of health, healing and wholeness so elusive. If acknowledging openness means suspending pre-judgment, for example on the realism of expectancy in the face of death, these words may take on counterintuitive meanings:

"A physically dependent patient who has come to terms with his past life and his approaching death, for example, may well feel, and thus (because no one else is better placed to judge) be nearer to 'wholeness' than ever before."26

Such a person may even, in this perspective, be described as "healthy".

Whether such counterintuitive meanings are entertained of course, depends on whether the viewpoint of the conscious knowing subject is given at least as much weight as that of the clinical observer. Canguilhem sums up the results of much physiological, pathological and clinical observation as follows.

"Life tries to win against death in all the senses of the verb to win, foremost in the sense of winning in gambling. Life gambles against growing entropy." ${ }^{27}$ 
But what if entropy grows too great, and life's last throw seems lost? Should the subject in whom life has grown conscious recognise that this time the odds are stacked too heavily against him? Or do all life's attempts to win against death hint to him that a deeper game, with higher stakes, is afoot? Religious arguments underdetermine any conclusive answer to this question. But so too do arguments which reduce first-person experience to third-person psychological, sociological or evolutionary explanations, or reduce the experienced mystery of being a conscious subject to a set of "eventually" solvable scientific problems about the property of consciousness. The disconcerting openness of experience raises a question mark against the conventional assumption that expectancy in the face of death is "no longer available" to critical thought. Might not a more critical stance be to admit ignorance without denying admission to hope? It is difficult to see why that should not remain at least an open question; and as long as it does, the meaning of health, healing and wholeness seems likely to remain elusive.

Kenneth M Boyd is Senior Lecturer in Medical Ethics, Edinburgh University Medical School and Research Director, Institute of Medical Ethics.

\section{References}

1 Brown L, ed. The new shorter English dictionary. Oxford: Clarendon Press, 1993.

2 Marinker M. Why make people patients? fournal of Medical Ethics 1975:I:81-4

3 Showalter E. Hystories. London: Picador, 1997.
4 Micale MS. Strange signs of the times. Times Literary Supplement 1997 May 16: 6-7

5 Unwin C, Blatchley N, Coker W, Ferry S, Hotopf M, Hull L, et al. Health of UK servicemen who served in the Persian Gulf War. Lancet 1999;353:169-78

6 Walton J, Barondess JA, Lock L, eds. The Oxford medical companion. Oxford: Oxford University Press, 1994: 611.

7 Youngson RM. Collins dictionary of medicine. Glasgow: HarperCollins, 1992: 406 .

8 See reference 6: 816 .

9 Hare RM. Health. Fournal of Medical Ethics 1986;12:172-81.

10 Tillich P. The meaning of health. Richmond, California: North Atlantic Books 1981: 43. See also: Kant I. Anthropology from a pragmatic point of view. [Translated by MJ Gregor.] The Hague: Martinus Nijhoff, 1974: 82-83.

11 Downie RS, Fyfe C, Tannahill A. Health promotion: models and values. Oxford: Oxford University Press, 1992.

12 Leach E. Society's expectations of health. Fournal of Medical Ethics 1975;1:85-9.

13 Treves F. The elephant man, and other reminiscences. London: Cassell 1923: 201.

14 Nietzsche F. The gay science. [Translated by W Kaufmann.] New York: Vintage Books, 1974: book III, section 120.

15 Canguilhem G. The normal and the pathological. New York: Zone Books, 1991: 196f.

16 See reference 15: 201

17 Schrödinger E. What is life? Cambridge: Cambridge University Press 1967: 118f.

18 Chalmers DJ. The conscious mind. Oxford: Oxford University Press, 1996: 162.

19 Heisenberg W. The physicist's conception of nature. London: Hutchinson, 1958: 29.

20 Dennett DC. Our mind's chief asset. Times Literary Supplement 1997 May 16: 5.

21 Schrödinger E. Nature and the Greeks. Cambridge: Cambridge University Press 1996:6.

22 See reference 21: 8

23 Kierkegaard S. Eighteen upbuilding discourses. [Translated by HV Hong and EH Hong.] Princeton: Princeton University Press 1990: 27.

24 Coleridge ST. Essay on faith. In: Aids to reflection. London: G Bell \& Sons, 1913: 341.

25 Coleridge ST. Biographia literaria. London: Bell \& Daldy, 1870: 144

26 Boyd KM. Health care ethics, health and disease. In: Gillon R, ed. Principles of health care ethics. Chichester: John Wiley \& Sons 1994: 812.

27 See reference 15: 236. 